\title{
PERENCANAAN PONDASI TIANG PANCANG GEDUNG DINAS TENAGA KERJA DAN TRANSMIGRASI
}

\author{
Ahmada Khotibul umam*1, Sigit Winarto ${ }^{2}$, Ahmad Ridwan ${ }^{3}$ \\ 1,2,3 Fakultas Teknik, Universitas Kadiri \\ email: ${ }^{* 1}$ ahmadakhotib@gmail.com, 2 sigit.winarto@unik-kediri.ac.id, \\ 3ahmad ridwan@unik-kediri.ac.id, ${ }^{4}$ iwan candra@unik-kediri.ac.id.
}

\begin{abstract}
The foundation has an important role in the field of construction. The function of the foundation is to transport the building load to the subgrade, so the foundation must be planned with the right calculation so that the building is safe and stable. Pile foundation is one type of foundation used in building construction with heavy loads. In research, land investigations use SPT (Standard Penetration Test). The calculations include the carrying capacity of the soil, the loading of buildings, the dimensions and depth of the pile, and the stability of the controls. Calculation results obtained, loading on floors 1 to 3, totaling 4,463.5 Tons. The dimensions of the foundation are 0.6, with a cross-sectional area of 0.28274334 and a depth of $18 \mathrm{M}$. The need for strengthening the foundation is $600059.7 \mathrm{Kg}$. With bolt control stability 24,620 Tons $/ M^{2}>1.5$ Tons $/ M^{2}->$ Safe, shear 9,156 Tons $/ M^{2}>0,156$ Tons $/ M^{2}->$ Safe.
\end{abstract}

Keywords : Foundation, Pile, Reinforced Concrete, SPT (Standard Penetration Test), Soil Bearing Capacity.

\begin{abstract}
Abstrak
Pondasi memiliki peranan penting dalam bidang konstruksi. Fungsi pondasi sendiri yaitu meneruskan beban bangunan ke tanah dibawah pondasi menjadikan pondasi harus direncanakan dan diperhitungkan dengan tepat agar bangunan yang didirikan aman dan stabil. Salah satu jenis pondasi yang banyak digunakan yaitu pondasi tiang pancang. Pondasi tiang pancang merupakan salah satu jenis pondasi dalam yang banyak digunakan pada konstruksi yang memiliki beban berat. Dalam penelitian, penyelidikan tanah menggunakan metode SPT (Standart Penetration Test). Perhitungan yang dilakukan meliputi perhitunagn daya dukung tanah, Pembebanan bangunan, dimensi dan kedalaman tiang pancang, serta stabilitas control. Hasil dari perhitungan didapat, pembebanan lantai 1 sampai 3 sebesar 4663,5 Ton. Dimensi pondasi sebesar 0,6 M dengan luas penampang 0,28274334 M dan kedalaman $18 \mathrm{M}$. Kebutuhan tulangan pondasi yaitu $600059,7 \mathrm{Kg}$. Dengan stabilitas kontrol terhadap guling 24,620 Ton / $\mathrm{M}^{2}>1.5$ Ton / $\mathrm{M}^{2}->$ Aman, Gaya terhadap geser 9,156 Ton / $\mathrm{M}^{2}>0,156$ Ton / $\mathrm{M}^{2}->$ Aman.

Kata Kunci : Pondasi, Tiang pancang, Beton bertulang, SPT (Standart Penetration Test), Daya Dukung Tanah.
\end{abstract}




\section{PENDAHULUAN}

Perkembangan infrastruktur dalam bidang konstruksi di Indonesia semakin meningkat.[1][2] Pondasi menjadi bagian yang penting dalam bidang konstruksi karena berperan sebagai penopang bangunan. [3][4] Pondasi sendiri merupakan bagian bawah bangunan yang berfungsi meneruskan beban dari bangunan ke tanah. [5][6] Pentingnya peran pondasi dalam bidang kosntrusi menjadikan pondasi harus direncanakan dan diperhitungkan dengan tepat.[7] Secara umum pondasi dapat dibedakan menjadi pondasi dalam dan pondasi dangkal. Pemilihan jenis pondasi tergantung pada struktur atas dan juga struktur tanah yang ada. [8] Pondasi dangkal digunakan untuk konstruksi dengan beban ringan dengan kondisi tanah cukup baik, sedangkan pondasi dalam digunakan untuk konstruksi dengan beban berat. [9]

Pondasi tiang pancang merupakan salah satu jenis pondasi dalam [10]. Pondasi tiang pancang berfungsi sebagai penyalur beban pondasi melewati lapisan tanah dengan daya dukung rendah kelapisan tanah yang mempunyai kapasitas daya dukung tinggi yang relative cukup dalam di banding pondasi dangkal.[11] Daya dukung tiang pancang diperoleh dari daya dukung ujung (end bearing capacity) daya dukung geser atau selimut (fiction bearing capacity) .

Daya dukung tanah menjadi faktor penting dalam perencanaan pondasi.[12] Daya dukung tanah dapat diperoleh melalui penyelidikan Standar Penetrasi Test (SPT) ataupun Cone Penetration Test [13]. Dengan mengetahui daya dukung tanah yang ada, maka pondasi dapat direncanakan dengan tepat. Tujuan dari perencanaan ini yaitu untuk merencanakan pondasi tiang pancang pada gedung dinas tenaga kerja dan transmigrasi Kabupaten Tulungagung. Perencanaan meliputi serangkaian kegiatan yang dilaksanakan dengan berbagai perhitungan dan tahapan yang meliputi studi kelayakan dan perencanaan Teknik. Hal ini dilaksanakan guna mendapatkan hasil yang maksimal.

\section{METODE PENELITIAN}

\subsection{Pondasi Tiang Pancang.}

Tiang pancang dikategorikan sebagai displacement pile di mana di dalam pelaksanaannya, [14] tiang mendesak tanah disekitarnya sehingga daya dukung pondasi sangat dipengaruhi oleh tegangan lateral yang bekerja di sekeliling tiang termasuk bagian ujung pondasi.[15] Pondasi tiang pancang pada umumnya sudah dicetak di pabrik (pabrikasi) yang setelahnya dikirim ke lokasi pembangunan. Kapasitas tiang pancang dapat diketahui dengan pengolahan data pengujian lapangan seperti SPT ataupun CPT[16]. 


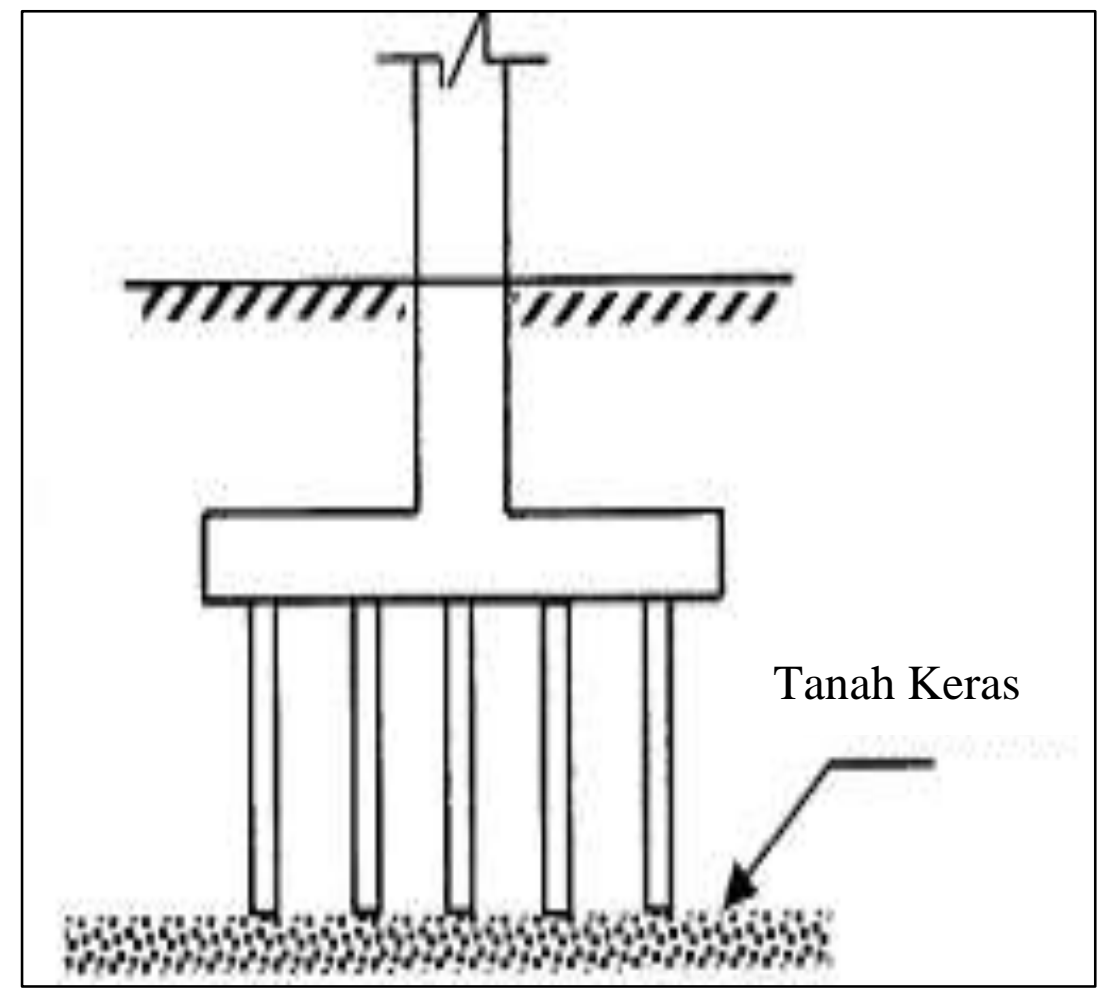

Sumber : Sketsa Pondasi Tiang Pancang.

Gambar 1. Pondasi Tiang Pancang.

\subsection{Daya Dukung Tanah.}

Daya dukung tanah adalah kemampuan tanah dalam dalam menahan struktur pondasi bangunan[17][18]. Pengujian lapangan dilakukan dengan cara pengujian pembebanan atau biasa disebut loading test. SPT banyak sekali digunakan untuk mendapatkan daya dukung tanah secara langsung Uji penetrasi standar (SPT) adalah tes penetrasi dinamis in-situ yang dirancang untuk memberikan informasi tentang sifat-sifat geoteknik tanah. Standart Penetration Test (SPT) dilakukan untuk mengestimasi nilai kerapatan relatif dari lapisan tanah yang diuji.

\subsection{Daya Dukung Ijin Tanah Pondasi Tiang Tunggal.}

Perencnaan suatu struktur pondasi dengan baik, hendaknya memahami dasar-dasar daya dukung tanah. Berikut rumus yang bisa digunakan untuk menghitung daya dukung tanah adalah metode Luciano Decourt (1982)[19].

Luciano Decourt (1982) :

$$
Q u=(A p \times N p \times K)+A s \times\left(\frac{N s}{3}+1\right) .
$$

Dimana :

$\mathrm{Qu}=$ Daya dukung ultimit tiang (Ton). 


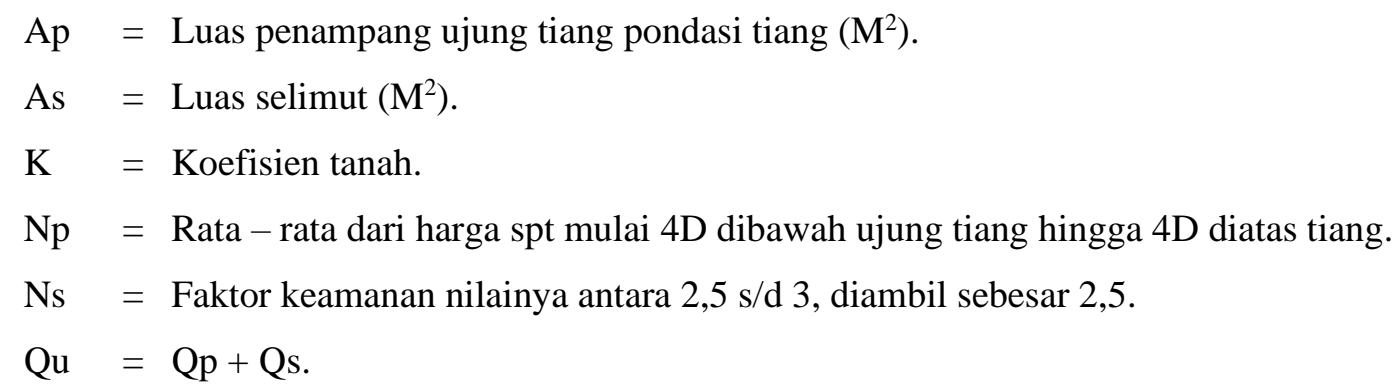

Dengan :

$\mathrm{Qu}=$ Daya dukung tanah maksimum pada pondasi.

$\mathrm{Qp} \quad=$ Resistance ultimit di dasar pondasi.

Qs = Resistance ultimit akibat lekatan lateral.

$\mathrm{Qp} \quad=\mathrm{qp} \times \mathrm{Ap}=(\mathrm{Np} \times \mathrm{K}) \times \mathrm{Ap}$.

Dimana :

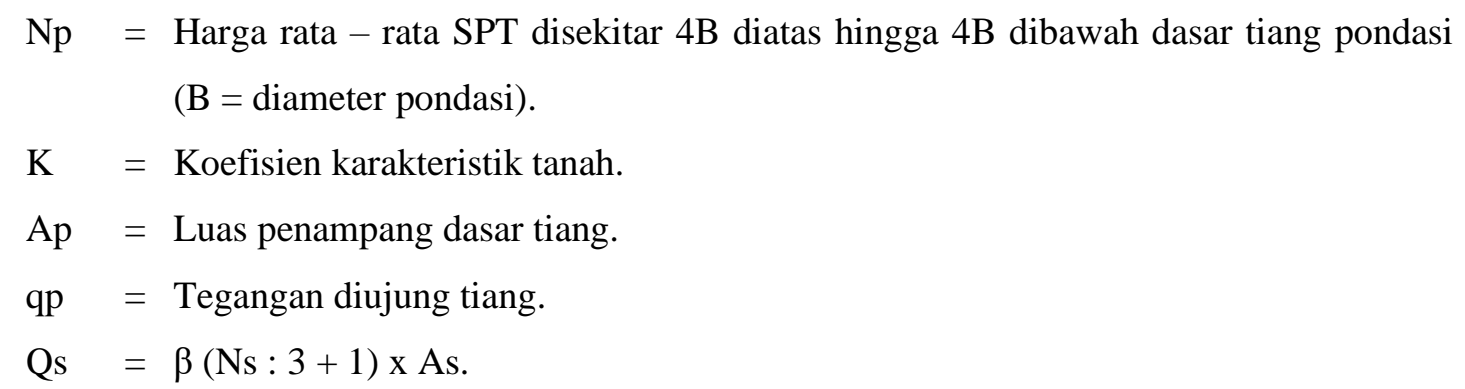

Dengan :

Qs = Tegangan akibat lekatan lateral (Ton).

$\beta=$ Shaft coefficient.

As $=$ Keliling $\times$ Panjang tiang $\left(\mathrm{M}^{2}\right)$.

Ns = Harga rata - rata sepanjang tiang terbenam.

\subsection{Daya Dukung Ijin Tanah Pondasi Tiang Grup.}

Pondasi tiang grup digunakan jika daya dukung ijin tanah pondasi tiang tunggal tidak mampu memikul beban struktur diatasnya.[20] Daya dukung tiang grup dapat dihitung menggunakan rumus berikut : $\quad$ Qug $=$ Qut $\times \mathrm{n} \times \mathrm{EFF}$.

Dimana :

Qug = Daya dukung ijin tiang grup.

Qut = Daya dukung ijin tiang tunggal.

$\mathrm{n} \quad=$ Jumlah tiang dalam grup.

$\mathrm{EFF}=$ Efisiensi tiang grup $(\leq 1)$. 


\subsection{Kebutuhan Jumlah Tiang.}

Perhitungan kebutuhan tiang pancang penting dilakukan guna mengetahui jumlah tiang yang dibutuhkan yntuk memikul beban maksimum [21]. Kebutuhan jumlah tian dapat dihitung menggunakan rumus berikut :

$$
n=\frac{\text { Beban yang dipikul }}{\text { Daya dukung ijin tiang tunggal }}=\frac{P u}{\text { Qut }} \quad \text { Atau } \quad n=\frac{\text { Beban Kolom }}{\text { Daya dukung ijin tiang tunggal }} \text {. }
$$

Dimana :

$$
\begin{aligned}
& \mathrm{n}=\text { Jumlah tiang. } \\
& \mathrm{Pu}=\text { Beban kolom terbesar. } \\
& \text { Qut }=\text { Daya dukung ijin tiang tunggal. }
\end{aligned}
$$

\subsection{Jarak Tiang $(S)$.}

Jarak antar tiang pancang didalam kelompok tiang sangat mempengaruhi dalam perhitungan kapasitas daya dukung dari kelompok tiang tersebut. [3] Untuk bekerja sebagai grup tiang jarak antara tiang (spacing) 'S'.

\subsection{Efisiensi Tiang Grup.}

Efisiensi tiang grup merupakan perbandingan kapasitas tiap kelompok terhadap kapasitas masing masing tiang. Perhitungan efisiensi kelompok tiang menggunakan metode Conversi-Labarre sebagai berikut : $E F F=1-\frac{\varphi}{90^{\circ}} X \frac{(n-1) m+(m-1) n}{m \cdot n}$ [22].

$\mathrm{EFF}=$ Efisiensi kelompok tiang.

$\Phi \quad=\operatorname{Arctg} \mathrm{d} / \mathrm{s}$, dalam derajat.

$\mathrm{m}=$ Jumlah baris tiang.

$\mathrm{n} \quad=$ Jumlah tiang dalam satu baris.

$\mathrm{d}=$ Diameter tiang.

$\mathrm{s} \quad=$ Jarak pusat ke pusat tiang.

\subsection{Pengolahan Data.}

Data yang sudah terkumpul akan diolah untuk mendapatkan hasil akhir untuk dengan uraian sebagai berikut :

A. Pengambilan data meliputi gambar lengkap (denah, potongan, detail - detail, denah pondasi, detail pondasi), data penyelidikan tanah yaitu data SPT.

B. Membaca dan mengutip studi literatur sebagai landasan teori.

C. Pengolahan data hasil penyelidikan tanah berupa hasil tes SPT, data tersebut sebagai perhitungan daya dukung tanahxtiang pancang (Daya Dukung ijin Tiang, Kapasitas Daya Dukung Tiang, Perhitungan Pile Cap). 


\section{HASIL DAN PEMBAHASAN}

\subsection{Perhitungan Pembebanan.}

Dari perhitungan pembebanan struktur (lantai 1 hingga lantai 3) sesuai dengan PBI 1983, didapat hasil sebagai berikut :
A. Beban hidup dan beban mati lantai 3
$=1.416 .260,4 \quad \mathrm{Kg}$.
B. Beban hidup dan beban mati lantai $2=1.537 .804,4 \quad \mathrm{Kg}$.
C. Beban hidup dan beban mati lantai $1=1.336 .110,4 \quad \mathrm{Kg}$.
* Total Pembebanan (Wt)
$=4290125,2 \quad \mathrm{Kg} . \quad=4.290,1$ Ton.

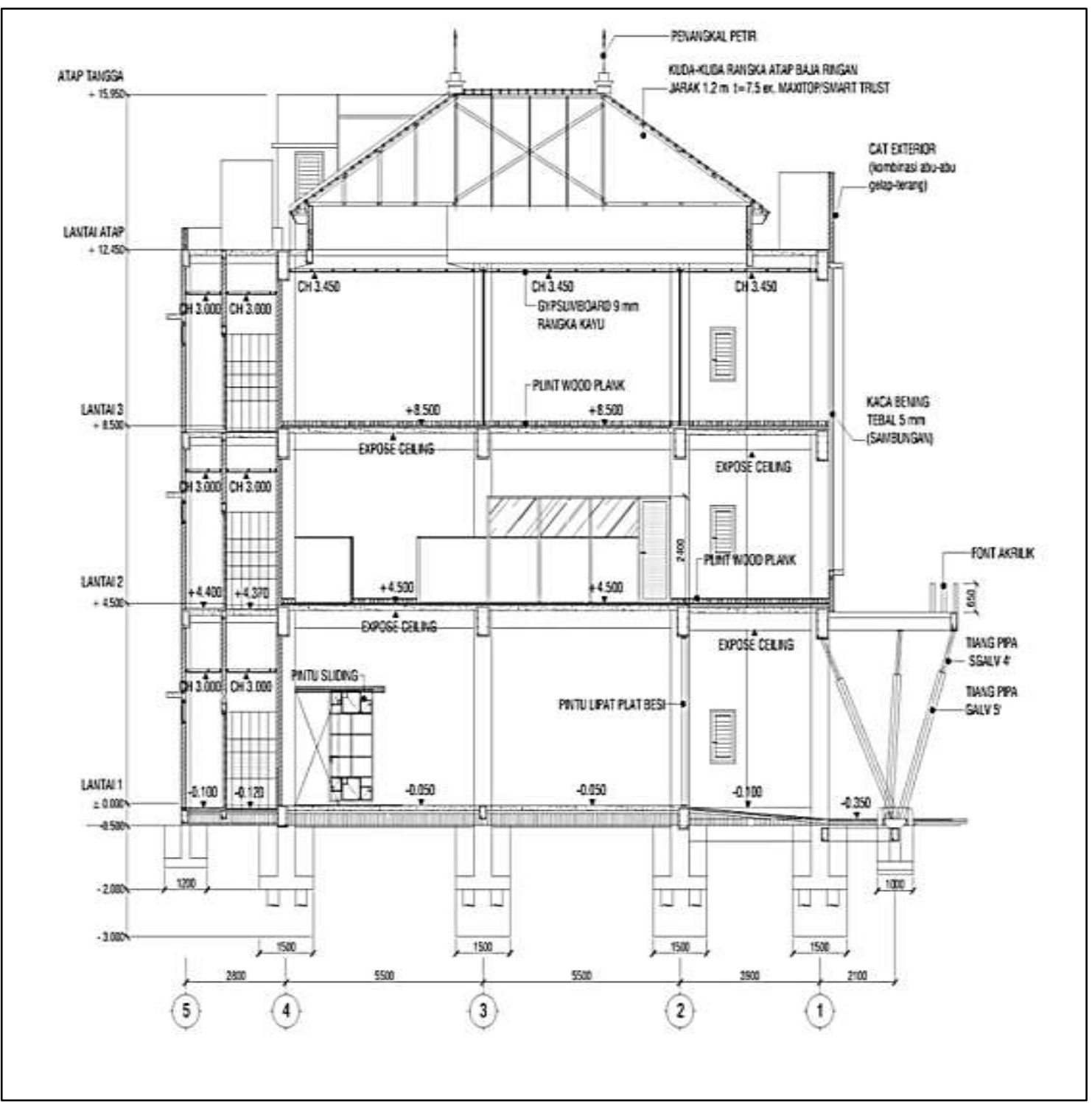

Sumber : Sketsa Gambar Kerja.

Gambar 2. Gambar Kerja. 


\subsection{Hasil Pengujian SPT.}

Hasil pengujian SPT (Standart Penetration Test) yang telah dilakukan dapat disajikan pada Tabel 1. berikut :

Tabel 1. Hasil pengujian SPT (Standart Penetration Test).

\begin{tabular}{|c|c|c|c|c|}
\hline Depth & DB1 & DB1 & DB2 & DB2 \\
\hline$(\mathrm{m})$ & $\mathrm{N}$ & Jenis Tanah & $\mathrm{N}$ & Jenis Tanah \\
\hline 0 & 0 & Lempung & 0 & Lempung \\
\hline 1 & 2 & Lempung & 2 & Lempung \\
\hline 2 & 4 & Lempung & 4 & Lempung \\
\hline 3 & 5 & Lempung & 5 & Lempung \\
\hline 4 & 5 & Lempung & 5.5 & Lempung \\
\hline 5 & 6 & Lempung & 6 & Lempung \\
\hline 6 & 7 & Lempung & 6 & Lempung \\
\hline 7 & 8.5 & Lempung & 7 & Lempung \\
\hline 8 & 12 & Lempung & 14 & Pasir \\
\hline 9 & 15 & Lempung & 23 & Pasir \\
\hline 10 & 15 & Lempung & 20 & Lempung \\
\hline 11 & 13.5 & Lempung & 14 & Lempung \\
\hline 12 & 15 & Lempung & 12 & Lempung \\
\hline 13 & 18 & Lempung & 12 & Lempung \\
\hline 14 & 20 & Lempung & 12 & Lempung \\
\hline 15 & 20 & Lempung & 13 & Lempung \\
\hline 16 & 19 & Pasir & 15 & Lempung \\
\hline 17 & 17.5 & Pasir & 19 & Pasir \\
\hline 18 & 15 & Lempung & 18 & Pasir \\
\hline 19 & 13.5 & Lempung & 17 & Pasir \\
\hline 20 & 16 & Lempung & 16 & Lempung \\
\hline 21 & 20 & Lempung & 15.5 & Lempung \\
\hline 22 & 18 & Lempung & 14.5 & Lempung \\
\hline 23 & 14 & Pasir & 14 & Lempung \\
\hline 24 & 16 & Pasir & 18 & Lempung \\
\hline 25 & 20 & Pasir & 23 & Pasir \\
\hline 26 & 22 & Pasir & 31 & Pasir \\
\hline 27 & 24 & Pasir & 40 & Pasir \\
\hline 28 & 34 & Pasir & 44 & Pasir \\
\hline 29 & 47 & Pasir & 49 & \\
\hline 30 & 50 & Pasir & & \\
\hline
\end{tabular}

Sumber : Hasil Uji SPT dilapangan. 


\subsection{Perencanaan Pondasi.}

A. Data Perencanaan.

Dimensi Tiang

Panjang

Luas (Ag)

Keliling

Luas Selimut Tiang
$=0.6$

M.

$=18$

M.

$=0,282743339 \mathrm{M}^{2}$.

$=1,884955592 \mathrm{M}$.

$=33,92920066 \quad \mathrm{M}^{2}$.

$\mathrm{Qp}=20 \times \mathrm{Np} \times \mathrm{A} \quad($ Luciano Decourt $)=186,61 \quad$ Ton.

$\mathrm{Qs}=((\mathrm{NS}: 3)+1) \times \mathrm{K}($ Luciano Decourt $)=279,92 \quad$ Ton.

$\mathrm{Q}_{\mathrm{ijin}}=((\mathrm{Qp}+\mathrm{Qs}): \mathrm{SF}) \quad=155,51 \quad$ Ton.

$\mathrm{SF}=3$

B. Efisiensi Tiang.

$$
E f f=1-\frac{\varphi}{90^{\circ}} x \frac{(\boldsymbol{n}-\mathbf{1}) \boldsymbol{m}+(\boldsymbol{m}-\mathbf{1}) \boldsymbol{n}}{\boldsymbol{m} \cdot \boldsymbol{n}}
$$

Dimana :

$\begin{array}{rlll}\mathrm{m} & =\text { Jumlah baris arah X } & =2 & \mathrm{bh} . \\ \mathrm{n} & =\text { Jumlah baris arah y } & =2 & \mathrm{bh} . \\ \mathrm{d} & =\text { Ukuran/diameter tiang pancang } & =60 & \mathrm{Cm} . \\ \mathrm{s} & =\text { Jarak antara tiang pancang } & =180 & \mathrm{Cm} . \\ \varphi & =\arctan \mathrm{d}: \mathrm{s} . & & \end{array}$

$$
\begin{aligned}
E f f & =1-\frac{18.43}{90} \times \frac{\mathbf{4}}{\mathbf{4}} \\
& =0.79516 \text { Ton. }
\end{aligned}
$$

C. Daya Dukung Tiang Tunggal

Reaksi Kolom Terbesar

Daya Dukung Ijin Tanah

Jumlah Tiang dibutuhkan
$=155,51 \times 0,79516$.

$=123,65553$ Ton.

$=250,25765$ Ton.

$=123,66 \quad$ Ton.

$=3.02(4.00) \mathrm{bh}$. 
D. Beban Maksimal Tiang.

Dengan :

$$
\operatorname{Pmax}=\frac{\Sigma \mathrm{Pv}}{\mathrm{n}} \pm \frac{\mathrm{Mx} \cdot \mathrm{Ymax}}{\mathrm{nx} \cdot \Sigma \mathrm{y}^{2}} \pm \frac{\mathrm{My} \cdot \mathrm{Xmax}}{\mathrm{ny} \cdot \Sigma \mathrm{x}^{2}}
$$

$$
\begin{aligned}
& \Sigma \mathrm{Pv}=\mathrm{Pu} \text { dari SAP }+ \text { berat pile cap } \quad=275,14 \\
& \mathrm{n}=\text { Banyaknya tiang dalam kelompok tiang } 4=4 \text {. } \\
& \mathrm{Mx}=\text { Momen } \operatorname{arah} \mathrm{X}=5,2 . \\
& \text { My }=\text { Momen arah Y }=3,28 \text {. } \\
& \mathrm{nX}=\text { Banyaknya tiang dalam arahX } 2=2 \text {. } \\
& \text { ny }=\text { Banyaknya tiang dalam arahY } 2=2 \text {. } \\
& \mathrm{Xmax}=\text { Absis terjauh tiang ke ttk brt klmpk tiang }=0,9 \text {. } \\
& \text { Ymax }=\text { Ordinat terjauh tiang ke ttk brt klmpk tiang }=\quad 0,9 \text {. } \\
& \Sigma \times 2 \text { kuadrat absis tiang }=3,24 \text {. }
\end{aligned}
$$

\begin{tabular}{|c|c|c|c|c|}
\hline F3 (Ton) & Berat pile cap (Ton) & Pv (Ton) & Mx (T.M) & My (T.M) \\
\hline 250.25765 & 24.88 & 275.14 & 5.20 & 3.28 \\
\hline
\end{tabular}

Pmax $<$ Daya dukung tiang tunggal $\quad=69.05<123.66 \ldots$ ok!

\subsection{Stabilitas kontrol.}

Dikarenakan pondasi tpe 1 dan 2 hampir sama maka stabilitas hanya dihitung salah satu tipe saja. Namun harus tetap dilakukan kontrol terhadap kontruksi pondasi dengan sebagai berikut :

- Kontrol terhadap guling

$$
\begin{array}{ll}
24,620 \mathrm{t} / \mathrm{m} 2>1,5 \mathrm{t} / \mathrm{m} 2 & \rightarrow \text { Aman. } \\
9,156 \mathrm{t} / \mathrm{m} 2>1,5 \mathrm{t} / \mathrm{m} 2 & \rightarrow \text { Aman. }
\end{array}
$$

- Kontrol terhadap geser

Kontrol penurunan kekuatan tumit:

- Kontrol terhadap geser

- Kontrol terhadap tarik

Kontrol kekuatan kaki :

- Kontrol terhadap geser

- Kontrol terhadap tarik

Kontrol kekuatan badan :

- $\sigma . \max$

- $\sigma . \min$

$$
\begin{aligned}
& -1,2779 \mathrm{t} / \mathrm{m} 2<15 \mathrm{t} / \mathrm{m} 2 \quad->\text { Aman. } \\
& -0,7606 \mathrm{t} / \mathrm{m} 2<30 \mathrm{t} / \mathrm{m} 2 \quad->\text { Aman. }
\end{aligned}
$$

$$
\begin{aligned}
& 1,3762 \mathrm{t} / \mathrm{m} 2<15 \mathrm{t} / \mathrm{m} 2 \quad \rightarrow \text { Aman. } \\
& 2,7676 \mathrm{t} / \mathrm{m} 2<30 \mathrm{t} / \mathrm{m} 2 \quad \rightarrow \text { Aman. }
\end{aligned}
$$




\section{KESIMPULAN}

Berdasarkan perencanaan pondasi tiang pancang di Gedung DINAS TENAGA KERJA DAN TRANSMIGRASI didapat beberapa kesimpulan, yakni sebagai berikut :

1. Dimensi serta kedalaman pondasi rencana yang digunakan adalah pada Pondasi tipe 1 Dimensinya adalah 0,6 M. dengan luas penampang dasar tiang 0,28274334 dan kedalaman $18 \mathrm{M}$ dari permukaan tanah. Pada Pondasi tipe 2 Dimensinya adalah 0,6 M dengan luas penampang dasar tiang 0,28274334 dengan kedalaman $18 \mathrm{M}$ dari permukaan tanah.

2. Kebutuhan Tulangan pondasi rencana yang digunakan adalah pada Pondasi Tiang Pancang tipe 1 menggunakan besi diameter $22 \mathrm{~mm}$, jarak $100 \mathrm{~mm}$, jumlah besi per pile cap 25 buah. total tulangan yang diperlukan 19.747,4 Kg. Pada tulangan Pondasi tiang pancang tipe 2 menggunakan besi diameter $22 \mathrm{~mm}$, jarak $50 \mathrm{~mm}$, jumlah besi per pile cap 40 buah. Dengan total tulangan yang diperlukan adalah $35.342,4 \mathrm{Kg}$.

\section{SARAN}

Beberapa saran dari penyusun yang perlu diperhatikan dalam merencanaan bangunan adalah pada perencanaan pondasi harus berpedoman pada ilmu literatur yang sesuai dan dapat dilaksanakan di lokasi proyek. Ketepatan estimasi dan analisa beban harus selalu diperhatikan agar target konstruksi aman dan dapat mengikuti alur Time Shcedule dari perencanaan.

\section{UCAPAN TERIMA KASIH}

Ucapan Terima kasih saya menyampaikan kepada semua pihak yang telah membantu saya dalam proses penulisan ini sampai bisa diselesaikan terutama kepada kedua orang tua, dosen pembimbing, dosen penguji dan teman - teman yang selalu setia membantu saya. 


\section{DAFTAR PUSTAKA}

[1] A. I. Candra, S. Anam, Z. B. Mahardana, and A. D. Cahyono, "Studi Kasus Stabilitas Struktur Tanah Lempung Pada Jalan Totok Kerot Kediri Menggunakan Limbah Kertas," UKaRsT, vol. 2, no. 2, pp. 88-97, 2018.

[2] A. I. Candra, H. Wahyudiono, S. Anam, and D. Aprillia, "KUAT TEKAN BETON Fc' 21, 7 MPa MENGGUNAKAN WATER REDUCING AND HIGH RANGE ADMIXTURES," vol. 5, no. 1, 2020.

[3] D. D. Saputro, "Studi pengaruh jarak tiang pancang pada kelompok tiang terhadap perubahan dimensi pile cap,” Konstruksia, vol. 571, no. 1, pp. 85-93, 2013.

[4] B. A. Wiratmoko, S. Winarto, and Y. C. SP, "PERENCANAAN PONDASI TIANG PANCANG GEDUNG KETAHANAN PANGAN NGANJUK," Jurmateks, vol. 2, no. 1, pp. 106-120, 2019.

[5] A. Yusti and F. Fahriani, "Analisis Daya Dukung Pondasi Tiang Pancang Diverifikasi dengan Hasil Uji Pile Driving Analyzer Test dan Capwap,” vol. 2, pp. 19-31, 2014.

[6] L. Sintyawati, S. Winarto, A. Ridwan, and A. I. Candra, "STUDI PERENCANAAN STRUKTUR PONDASI TIANG PANCANG GEDUNG FAKULTAS SYARIAH IAIN PONOROGO,”Jurmateks, vol. 1, no. 2, pp. 227-237, 2018.

[7] F. Luthfiani, "Analisis penurunan bangunan pondasi tiang pancang dan rakit pada proyek pembangunan apartemen surabaya central business district," J. KARYA Tek. SIPIL, vol. 6, no. 2, pp. 166-179, 2017.

[8] K. Prayogo and H. Saptowati, "Penyelidikan struktuur dan karakteriistik tanah untuk desain Pondasi Iridiatir Gamma kapasitas 2 MCi,” J. Perangkat Nukl., vol. 10, no. 1, pp. 30-49, 2016.

[9] J. F. Vol et al., "Analisis Data Geolistrik Dan Data Uji Tanah Untuk Menentukan Struktur Bawah Tanah Daerah Skyland Distrik Abepura Papua," J. Fis., vol. 3, no. 1, 2013, doi: 10.15294/jf.v3i1.3965.

[10] I. Mustofa, S. Winarto, and A. Ridwan, "PERENCANAAN PONDASI TIANG PANCANG PADA GEDUNG UNIVERSITAS TULUNGAGUNG,"Jurmateks, vol. 1, no. 2, pp. 216-226, 2018.

[11] M. I. G. SYAFEI, I. B. Mochtar, and Y. Lastiasih, "Perencanaan Pondasi Tiang Pancang Dengan Memperhitungkan Pengaruh Likuifaksi Pada Proyek Pembangungan Hotel Di Lombok,” J. Tek. ITS, vol. 5, no. 2, 2016, doi: 10.12962/j23373539.v5i2.19111. 
[12] A. I. Candra, A. Yusuf, and A. R. F, "Studi Analisis Daya Dukung Pondasi Tiang Pada Pembangunan Gedung Lp3m Universitas Kadiri,” CIVILLa, vol. 3, no. 2, pp. 166-171, 2018.

[13] F. Fahriani and Y. Apriyanti, “Analisis Daya Dukung Tanah Dan Penurunan Pondasi Pada Daerah Pesisir Pantai Utara Kabupaten Bangka," Forum Prof. Tek. Sipil, vol. 3, no. 2, pp. 89-95, 2015, doi: 10.33019/fropil.v3i2.1219.

[14] T. R. Saptorini, "TERHADAP HASIL UJI CALENDERING ( Studi Kasus Review Design Pada Overpass Lemah Ireng Sta $20+212$ Proyek Jalan Tol Semarang - Bawen Paket V ).”

[15] J. T. Sipil, "KAJIAN PENGARUH SETUP PADA TIANG PANCANG TERHADAP PENINGKATAN DAYA DUKUNG PONDASI (Studi Kasus Porto dan Jakarta),” J. Tek. Sipil Unika Soegijapranata, vol. 3, no. 1, pp. 16-26, 2006.

[16] F. Teknik, J. Sipil, U. Sam, and R. Manado, "Pengaruh jenis tanah dan bentuk tiang pancang terhadap kapasitas daya dukung tiang pancang grup akibat beban vertikal," vol. 6, no. 5, pp. 339-352, 2018.

[17] A. I. Candra, "Analisis Daya Dukung Pondasi Strauss Pile pada Pembangunan Gedung Mini Hospital Universitas Kadiri," Ukarst, vol. 1, no. 1, pp. 63-70, 2017.

[18] Pontjo Utomo, "Daya Dukung Ultimit Pondasi Dangkal Di Atas Tanah Pasir Yang Diperkuat Geogrid," Civ. Eng. Dimens., vol. 6, no. 1, pp. 15-20, 2004.

[19] M. S. Putri, Y. Apriyanti, and F. Fahriani, "Analisis perbandingan daya dukung dan penurunan tiang pancang tunggal dengan metode statik dan uji beban," Pros. Semin. Nas. Penelit. Dan Pengabdi. Pada Masy., vol. 2, pp. 1-6, 2018, doi: https://doi.org/10.33019/snppm.v2i0.624.

[20] S. Balamba and L. D. K. Manaroinsong, "Pancang Kelompok Akibat Beban Lateral," vol. 7, no. 11, 2019.

[21] N. Nuryanto and S. Wulandari, "Perencanaan Pondasi Tiang Pada Tanah Lempung," Pros. PESAT, vol. 5, no. 0, pp. 8-9, 2013.

[22] S. Trenggana, "Analisa Perhitungan Pile - Raft Foundation pada Proyek the 18 Office Park Jakarta,” J. Tek. Sipil dan Lingkung., vol. 2, no. 3, pp. 583-591, 2014. 